\title{
Hubungan Antara Curahan jam kerja dan Fertilitas Wanita Pasangan Usia Subur (PUS) di Kelurahan Loloan Timur Kecamatan Jembrana Kabupaten Jembrana
}

\author{
Fikrrotul Hasanah 1 , I Putu Ananda Citra ${ }^{2}$, dan I Made Sarmita ${ }^{3}$ \\ Jurusan Pendidkan Geografi \\ Universitas Pendidikan Ganesha \\ Singaraja, Indonesia \\ email: vikayongwa@gmail.com¹,ananda.citra@undiksha.ac.id², \\ Madesarmita@ymail.com ${ }^{3}$
}

\begin{abstract}
ABSTRAK
Penelitian ini dilaksanakan di Kelurahan Loloan Timur Kecamatan Jembrana Kabupaten Jembrana dengan tujuan: (1). Mendiskripsikan karakteristik wanita PUS di Kelurahan Loloan Timur Kecamatan Jembrana Kabupaten Jembrana. (2). Mendiskripsikan fertilitas wanita PUS di Kelurahan Loloan Timur Kecamatan Jembrana Kabupaten Jembrana. (3). Menganalisi hubungan antara curahan jam kerja dan fertilitas wanita PUS di Kelurahan Loloan Timur Kecamatan Jembrana Kabupaten Jembrana. Penelitian ini dirancang sebagai penelitian deskriptif dengan sampel sebesar 10\% dari populasi ( 901 wanita PUS yang bekerja ) yang diambil secara Proportional Random Sampling. Pengumpulan data primer menggunakan metode wawancara, dan data sekunder menggunakan pencatatan dokumen, yang selanjutnya dianalisis dengan metode deskriptif kuantitatif dan kualitatif.

Hasil penelitian menunjukkan bahwa (1). Wanita pasangan usia subur di Kelurahan Loloan Timur memiliki tingkat konsisten dalam mengatur curahan jam kerja yaitu dominan 7-9 jam/hari dapat digolongkan wanita PUS tergolong pekerja penuh. (2).Fertilitas wanita PUS di Kelurahan Loloan Timur bervariasi jumlah anak yang dimiliki wanita PUS yang terdapat di Loloan Timur kesadaran ber-KB dari wanita PUS masih tergolong rendah karena masih banyaknya jumlah anak yang tidak teratur. (3). Terdapat hubungan yang signifikan anatara curahan jam kerja dan fertilitas wanita PUS di Kelurahan Loloan Timur nilai signifikansi (sig.(2-tailed)) 0,000 0,05.
\end{abstract}

Kata kunci: Curahan jam kerja, Fertilitas, Wanita Pasngan Usia Subur (PUS) 


\title{
The Correlation Working Hours And Fertility In Women Of Childbearing Age (PUS) In East Loloan Village Jembrana Sub-District Jembrana Regency
}

\begin{abstract}
This research was conducted in East Loloan village, Jembrana sub-district, Jembrana regency and aimed at: (1) describing the characteristics of women of childbearing age (PUS) in East Loloan village, Jembrana sub-district, Jembrana regency; (2) describing the fertility in women of childbearing age (PUS) in East Loloan village, Jembrana sub-district, Jembrana regency; and (3) analyzing the correlation between working hours and fertility in women of childbearing age (PUS) in East Loloan village, Jembrana sub-district, Jembrana regency. This research was designed in form of descriptive research with a sample of $10 \%$ of the population (901 women of childbearing age (PUS) who are working). The sample was taken by using Proportional Random Sampling. The primary data was collected using interview method and the secondary data was obtained using record-keeping method, which was further analyzed using qualitative and quantitative descriptive methods. The results of the research showed that (1) women of childbearing age (PUS) in East Loloan village has a regular working hours -7 to 9 hours/ day and could be categorized as fulltime workers; (2) The fertility in women of childbearing age (PUS) in East Loloan village varies in terms of the number of children they have. Their awareness of Birth Control (KB) is still very low because the numbers of children possessed among the women are varied and irregular; and (3) there is a significance correlation found between the working hours and fertility in women of childbearing age (PUS) in East Loloan village by looking at the significant value (sig.(2-tailed)) $0.000<0.05$.
\end{abstract}

Keywords: working hours, fertility, women of childbearing age (PUS) 


\section{PENDAHULUAN}

Penduduk merupakan objek dan subjek pembangunan, sehingga diperlukan penduduk dengan kualitas yang memadai agar dapat menunjang laju pertumbuhan ekonomi. Upaya yang dilakukan sebagai usaha untuk meningkatkan kualitas penduduk, yaitu melalui penyediaan kualitas pendidikan, perluasan lapangan pekerjaan, dan penundaan usia kawin pertama. Jumlah penduduk yang banyak merupakan sumber daya potensial dalam pembangunan, tetapi perlu diingat bahwa pertumbuhan penduduk yang terlalu cepat sering kali tidak diimbangi oleh penyediaan sarana yang memadai. Akibatnya, pertambahan penduduk tidak potensial lagi bahkan menjadi beban bagi pembangunan.

Pertumbuhan penduduk merupakan perubahan jumlah penduduk baik bertambah maupun bertambah maupun berkurangyang disebabkan oleh tiga variabel utama demografi yaitu fertilitas, mortalitas, migrasi. Fertilitas adalah komponen yang dapat menambah jumlah penduduk, mortalitas merupakan komponen yang dapat menguranngi jumlah penduduk, dan migrasi merupakan komponen yang dapat menambah atau mengurangi jumlah penduduk. Faktor migrasi secara nasional, dapat dikatakan sedikit memiliki pengaruh terhadap turunnya pertumbuhan penduduk tersebut. Pada sisi lainnya, faktor mortalitas jelas dapat dikatakan tidak berpengaruh terhadap turunnya laju pertumbuhan penduduk karena pada saat bersamaan, angka harapan hidup penduduk Indonesia selalu mengalami peningkatan. Faktor yang diduga penting jelas berpengaruh adalah turunnya fertilitas akibat keberhasilan program KB.

Wanita dinilai mampu untuk memberikan sumbangan lebih dari sekedar pekerjaan rumah tangga atau tidak hanya terbatas pada pelayanan terhadap suami, mengurus anak serta pekerjaan rumah tangga. Wanita dewasa ini sudah terlibat dalam kegiatandi luar rumah (Sektor Publik) yang menghasilkan pendapatan. Hal tersebut dilakukan oleh sebagian wanita tidak semata-mata di dorong oleh keadaan ekonomi keluarga yang menuntut tetapi juga didorong oleh faktor lain, seperti pendidikan wanita yang semakin meningkat, peluang kerja dan waktu luang yang dimiliki wanita. Tentu saja kegiatan di luar rumah menjadikan wanita memiliki peran ganda, di satu sisi mengurus rumah tangga dan disisi lain bekerja untuk menghasilkan pendapatan.

Aktivitas wanita pasangan usia subur dapat dilihat dari jenis pekerjaan yang dilakukan dan curahan jam kerja yang dijalani, aktivitas wanita pasangan usia subur dapat berpengaruh pada fertilitasnya, wanita yang beraktivitas tinggi cenderung akan mengharapkan fertilitas yang rendah, sehingga tidak mengganggu aktivitasnya, namun pada masyarakat tertentu budaya, sosial dan ekonomi masih berperan dalam mempengaruhi fertilitas, selain itu sejak masa reformasi dengan otonomi daerah keluarga berencana $(\mathrm{KB})$ tidak mendapat perhatian seperti sebelumnya sehingga fertilitas meningkat.

Peningkatan jumlah penduduk di Kelurahan Loloan Timur diduga ada kecendrungan oleh meningkatnya angka kelahiran. Mengacu pada data yang diperoleh di Puskesmas Pembantu (PUSTU) Kelurahan Loloan Timur, memperlihatkan bahwa terjadi kenaikan jumlah kelahiran dalam lima tahun terakhir yakni dari tahun 2012 berjumlah 158 jiwa kelahiran di tahun 2016 meningkat menjadi 286 jiwa kelahiran.

Tabel 1 Kelahiran bayi di Kelurahan Loloan Timur

\begin{tabular}{|c|c|c|c|}
\hline \multirow{2}{*}{ Tahun } & \multicolumn{2}{|c|}{ Kelahiran } & \multirow{2}{*}{$\begin{array}{c}\text { Jumlah } \\
\text { (jiwa) }\end{array}$} \\
\cline { 2 - 3 } & $\begin{array}{c}\text { Laki- } \\
\text { laki }\end{array}$ & Perempuan & \\
\hline 2012 & 74 & 84 & 158 \\
\hline 2013 & 99 & 81 & 180 \\
\hline 2014 & 109 & 112 & 221 \\
\hline 2015 & 111 & 124 & 235 \\
\hline
\end{tabular}




\begin{tabular}{|l|l|l|l|}
\hline 2016 & 105 & 181 & 286 \\
\hline
\end{tabular}

Semakin meningkatnya fertilitas di Loloan Timur tentu tidak bisa terjadi sebagai variabel tunggal. Fertilitas dipengaruhi oleh beberapa variabel dan wanita memiliki peran didalamnya. Beberapa variabel terdapat pada wanita yang berkontribusi terhadap dinamika fertilitas antara lain jenis pekerjaan termasuk juga curahan jam kerja wanita.

Wanita bekerja dengan kebutuhan rumah tangga yang masih kurang adalah mereka yang diharuskan bekerja untuk memenuhi kebutuhan hidup. Para wanita banyak mencurahkan waktunya untuk bekerja. Pekerja wanita di Kelurahan Loloan Timur Kecamatan Jembrana Kabupaten Jembrana banyak memiliki variasi pekerjaan seperti, petani, buruh tani, PNS, pedagang keliling, peternak, dokter, bidan, pembantu rumah tangga di Kelurahan Loloan Timur, yang melatar belakangi wanita untuk bekerja bahwa wanita membutuhkan pekerjaan untuk memenuhi kebutuhan hidup.

Variasi aktivitas pekerjaan tentu berimplikasi terhadap variasi curahan jam kerja. Secara umum wanita mempunyai peran baik sebagai ibu rumah tangga maupun pencari nafkah yang tercermin dalam curahan waktu kerja wanita. Curahan waktu kerja wanita secara garis besar dibagi menjadi dua, yaitu curahan waktu kerja untuk kegiatan ekonomi (mencai nafkah) dan kegiatan non ekonomi yaitu, kegiatan dasar, kegiatan sosial, dan kegiatan rumah tangga. Umumnya pekerjaan di Kelurahan Loloan Timur tidak hanya bekerja satu jenis pekerjaan, waktu yang diluangkan keluarga pada berbagai pekerjaan juga berbeda-beda tergantung tingkat upah atau pendapatan yang diterima, pada umumnya di Kelurahan Loloan Timur suatu rumah tangga terlibat pada berbagai jenis pekerjaan.

Adapun faktor sosial yang mempengaruhi curahan jam kerja wanita antara lain, total pendapatan rumah tangga tenaga kerja wanita, pendidikan tenaga kerja wanita, umur tenaga kerja wanita, jumlah anggota keluarga, ada atau tidak ada anak balita, upah tenaga kerja wanita. Dengan adanya faktor-faktor tersebut dapat mempengaruhi atau mendorong para wanita Kelurahan Loloan Timur untuk mengambil peran ganda dalam keluarga.

Masing-masing dari variabel tersebut diduga memiliki hubungan dengan tingkat fertilitas. Hal tersebut yang ingin dikaji lebih lanjut terutama di Kelurahan Loloan Timur Kecamatan Jembrana Kabupaten Jembrana, karena di Kelurahan tersebut sangat padat jumlah penduduknya dilihat dari kepadatan penduduknya dan Kelurahan Loloan Timur sangat tinggi tingkat fertilitasnya dilihat dari catatan kelahian bayi yang ada di Puskesmas Pembantu (PUSTU) LoloanTimur.

Rumusan masalah dalam penelitian ini adalah (1) Bagaimanakah karakteristik wanita PUS di Kelurahan Loloan Timur Kecamatan Jembrana Kabupaten Jembrana? (2) Bagaimanakah karakteristik fertilitas wanita PUS di Kelurahan Loloan Timur Kecamatan Jembrana Kabupaten Jembrana? (3) Bagaimanakah hubungan antara curahan jam kerja dan fertilitas wanita PUS di Kelurahan Loloan Timur Kecamatan Jembrana Kabupaten Jembrana?

\section{KAJIAN PUSTAKA}

Geografi penduduk merupakan salah satu cabang dari Geografi Manusia yang objek studinya adalah aspek keruanga dari penduduk. Aspek keruanga penduduk yang menjadi objek kajian dalam geografi penduduk mencangkup penyebaran penduduk, densitas (kepadatan) penduduk, perbandingn jenis kelamin (sex ratio), dan perbandingan manusia dengan luas tanah (man land ratio). Jadi secara singkat dapat dikatan bahwa segala aspek keruangan yang berkenaan denga manusia sebagai penduduk suatu wilayah menjadi bahan interpretasi dan analisis Geografi Penduduk.

Fertilitas (kelahiran hidup atau live brith) yaitu terlepasnya janin dari rahim 
seorang perempuan dengan ada tandatanda kehidupan: misalnya berteriak, bernapas, jantung berdenyut. Seorang perempuan yang secara biologis subur (fecund) tidak selalu melahirkan anakanak yang banyak, misalnya dia mengatur fertilitasnya dengan menggunakan alat kontrasepsi. Kemampuan biologis seorang perempuan untuk melahirkan sangat sulit untuk diukur (Mantra, 2003: 145).

Geografi penduduk selalu berkontribusi dengan fertilitas. Tiga aplikasi dan keterampian tertentu dari studi geografi dengan perspektif spasialnya mampu memberikan kontribusi yang penting untuk studi fertilitas yang dapat dikemukan sebagai berikut (Astawa 2016), (1) Teori Difusi dapat digunkan untuk menilai penyebaran dari pusat inovasi dan pengetahuan fertilitas, sikap dan prilaku, yang mana mekanismenya jarak relevan untuk memahami penggunaan variabel pusa layanan seperti klinik keluarga berencana. (2) Sebuah apresiasi identitas budaya daerah, didasarkan pada tradisi geografi regional klasik di Perancis, yang bisa membatu dalam memahami pola-pola terkait dengan perkembangan tahapan demogrfis yang dapat melintasi ruang. (3) Data territorial yang telah diilah dapat digunakan untuk melengkapi, atau mengganti data temporal dalam analisis hubungan antara pembagunan dan fertilitas.

Secara umum wanita mempunyai peran baik sebagai ibu rumah tangga maupun pencari nafkah yang tercermin dalam curahan jam kerja wanita. Curahan waktu kerja wanita secara garis besar dibagi menjadi dua, yaitu curahan waktu kerja untuk kegiatan ekonomi (mencari nafkah) dan kegiatan non ekonomi, yaitu kegiatan dasar, kegiatan social, dan kegiatan rumah tangga.

Pekerja adalah orang yang melakukan atau orang yang bekerja untuk tujuan menghasilkan pendapatan. Dalam hal ini dapat dilihat mereka yang bekerja adalah manusia. Berdasakan jenis kelamin manusia terdiri dari laki-laki dan wanita. Mereka yang bekerja dengan jenis kelamin wanita disebut sebagai pekerja wanita. Berkaitan dengan konsep pekerja.

Wanita merupakan jenis yang secara kodrati berbeda dengan laki-laki. Keberadaan wanita umumnya dikaitkan dengan ibu rumah tangga. Selama ini kegiatan wanita sebagai ibu rumah tangga tidak dipandang sebagai kegiatan ekonomi yang menghasilkan pendapatan (fakta domestic), Wanita dewasa ini sudah terlibat dalam kegiatan di luar rumah (Sektor Publik) yang menghasilkan pendapatan.

Keadaan perekonomian yang semakin tidak menentu, dengan harga-harga kebutuhan pokok yang semakin meningkat, serta pendapatan yang cenderung tidak menentu tentunya akan berakibat terganggunya stabilitas perekonomian keluarga. Kondisi seperti inilah mendorong wanita berperan ganda dengan tidak hanya menekuni sektor domestik (mengurus rumah tangga), namun ikut berpartisipasi di sektor publik dengan membantu suami mencari nafkah untuk penghidupan yang lebih layak.

karakteristik pekerja wanita yang sangat berpengaruh adalah berkaitan dengan adanya pekerja wanita menurut umur, status kawin wanita yang tidak menjadi batasan untuk bekerja, dilihat dari pendidikan, seseorang yang mempunyai pendidikan tinggi enggan untuk bekerja di sektor informal, sedangkan seseorang yang berpendidikan rendah rela bekerja di sektor apapun. Hal ini berkaitan dengan usaha dalam memenuhi kebutuhan, curahan waktu kerja yang dilihat dari jenis pekerjaan, jika jenis pekerjaan formal curaha waktu yang dicurahkan untuk bekerja sudah dapat ditentukan dan sebaliknya jika pekerjaan non formal curahan waktu untuk bekerja tidak dapat ditentukan.

Dalam analisis pekerja menurut status pekerjaan ada yang bertujuan untuk mengetahui status pekerjaan formal dan status pekerjaan informal. Pekerjaan pada status pekerjaan formal diasumsikan produktivitas kerja adalah lebih tinggi dari pekerja dengan status informal. Pendekatan informal dan formal menggunakan status pekerjaan dalam 
hubungannya dengan pendapatan atau produktivitas tidak seluruhnya benar, akan tetapi cukup bermanfaat untuk melihat kesempatan kerja yang ada dengan produktivitas kerja meskipun sangat kasar.

Pengaruh curah jam kerja terhadap fertilitas, kerja diartikan sebagai proses penciptaan atau pembentukan nilai baru pada suatu unit sumberdaya, pengubahan atau penambahan nilai pada suatu unit alat pemenuhan kebutuhan yang ada. Curahan waktu kerja tergantung dari jenis pekerjaan, kebutuhan ekonomi dan kesempatan kerja. Curahan waktu kerja yang dilihat dari jenis pekerjaan, jika jenis pekerjaan formal curaha waktu yang dicurahkan untuk bekerja sudah dapat ditentukan dan sebaliknya jika pekerjaan informal, curahan waktu untuk bekerja tidak dapat ditentukan. Keadaan ekonomi yang terpuruk akan meninggalkan curahan kerjanya sehingga akan dapat menghasilkan keuntungan yang maksimal dan sebaliknya.

\section{METODE}

Penelitian ini menggunakan desain deskriptif, Adapun yang di deskripsikan, adalah fertilitas, aktivitas wanita dan hubungan aktivitas wanita dengan fertilitas. Jenis penelitian ini adalah deskriptif korelasional yaitu penelitian yang dilakukan oleh peneliti untuk mengetahui tingkat hubungan antara dua variabel atau lebih, tanpa melakukan perubahan, tambahan atau manipulasi terhadap data yang memang sudah ada. Penggunaan metode dalam penelitian disesuaikan dalam masalah serta tujuan penelitian tersebut, dalam hal ini metode penelitian sangat penting untuk pelaksanaan, pengumpulan data, dan analisis data.

Objek dalam penelitian ini adalah fertilitas, hubungan jenis pekerjaan dan curahan jam kerja wanita dengan tingkat fertilitas di Kelurahan Loloan Timur, sedangkan subjek penelitian ini adalah pekerja wanita pasangan usia subur (PUS) di Kelurahan Loloan Timur.
Adapun jenis data yang dibutuhkan dalam penelitian ini adalah data primer yang meliputi: hubungan aktivitas wanita pasangan usia subur dengan fertilitas wanita pasangan usia subur. Populasi dari peneliti ini adalah seluruh jumlah wanita yang bekerja dan sudah menikah di Kelurahan Loloan Timur Kecamatan Jembrana Kabupaten Jembrana, yang termasuk dalam pasangan usia subur yaitu antara 15-49 tahun. Pengumpulan data dalam penelitian ini dilakukan dengan menggunakan teknik pencatatan dokumen dan Wawancara maka metode analisis yang digunakan dalam penelitian ini adalah analisis deskriptif.

Pendekatan yang digunakan dalam metode penelitian ini adalah pendekatan ekologi sebagai yang utama. Berarti tekanan yang diberikan dalam kajian ini adalah pada faktor-faktor lingkungan yang berperan dalam menimbulkan fenomena tingkat fertilitas di Kelurahan Loloan Timur.

Tahap awal analisis data dalam penelitian ini adalah menghitung jumlah jenis pekerjaan wanita pasangan usia subur untuk mengetahui curahan jam kerja pada wanita pasangan usia subur, kemudian setelah diketahui curahan jam kerja pada wanita akan diketahui hubungan jenis pekerjaan wanita dengan curahan jam kerja yang akan berpengaruh terhadap fertilitas, untuk melihat dan mengetahui hubungan antara 2 variabel tersebut adalah menggunakan korelasi product moment.

\section{HASIL DAN PEMBAHASAN Hasil}

Dalam penelitian ini disajikan hasil mengenai Deskripsi aktivitas jam kerja wanita pasangan usia subur (PUS), dan fertilitas wanita pasnagan usia subur (PUS).

Pekerja wanita pasangan usia subur pada Banjar Dinas di Kelurahan Loloan Timur memiliki tingkat konsistensi dalam mengatur curahan waktu kerja per hari yaitu 7-9 jam. Tetapi pada Banjar Dinas Ketugtug dan Mertasari terjadi ketidak konsistenan dalam mengatur curahan jam kerja pada pasangan usia subur, yaitu 4-6 jam dan 10-12 jam per 
hari. Untuk lebih jelasnya mengenai jumlah jam kerja harian pekerja wanita pasangan usia subur.

\section{Tabel 2 Karakteristik jumlah jam kerja harian pekerja wanita pasangan usia subur di Kelurahan Loloan Timur}

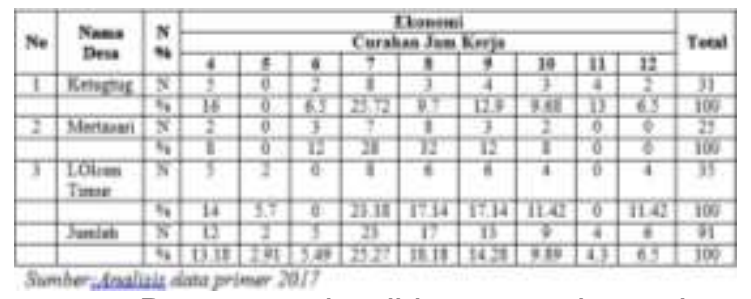

Dengan demikian curahan jam kerja wanita pasangan usia subur di Kelurahan Loloan Timur di dominasi 7-9 jam, berarti jam kerjanya seperti halnya PNS, dengan demikian aktivitas wanita pasangan usia subur tergolong pekerja penuh. Sedangkan curahan jam kerja 4-6 seperti halnya pekerja serabutan dan 1012 jam berprofesi sebagai pedagang kaki lima. Di dalam rumah tangga pada umumnya yang bekerja adalah kepala rumah tangga (suami). Tetapi jika pendapatan yang diperoleh oleh suami tidak dapat memenuhi kebutuhan rumah tangga, maka untuk memenuhinya istri akan ikut membantu mencari nafkah. Suatu pekerjaan dianggap sebagai pekerjaan pokok jika curahan waktu kerjanya akan lebih banyak dibandingkan dengan sambilan.

Pekerjaan sambilan akan diambil apabila pekerja telah menyelesaikan pekerjaan pokoknya, atau telah memiliki waktu luang. Pekerja wanita menggeluti pekerjaannya ada yang menjadikan sebagai pekerjaan pokok seperti PNS, Dokter, POLRI, Bidan tetapi ada sebagai pekerjaan sambilan seperti petani, buruh tani, pengrajin industri, kerja serabutan untuk menambah pendapatan rumah tangga dan membantu suami dalam mencari nafkah. Untuk lebih jelasnya tentang jenis pekerjaan wanita pasangan usia subur.

Tabel 3 Jenis Pekerjaan Aktivitas Wanita Pasangan Usia Subur (PUS) Kelurahan Loloan Timur

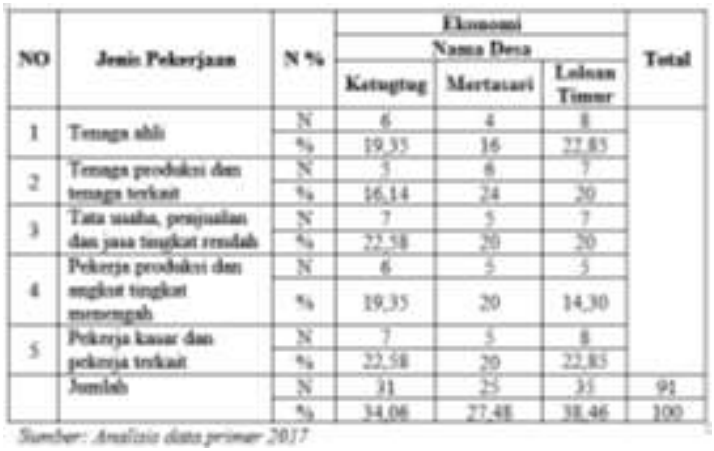

Aktivitas pekerja wanita yang terdapat di Kelurahan Loloan Timur dari 5 kategori jenis-jenis pekerjaan diatas mengacu pada buku Demografi Umum Ida Bagoes Mantra, yang paling dominan yaitu tenaga ahli seperti PNS, Polri, Dokter swasta, Bidan swasta. Untuk pekerja kasar dan pekerja terkait seperti, Petani, Buruh tani, Pembantu rumah tangga, Kerja serabutan, Buruh nelayan. Sedangkan untuk kategori jenis pekerjaan yang kurang diminati oleh pekerja wanita yaitu tenaga Ahli seperti, Dokter swasta, Bidan swasta. Jika dilihat dari Banjar Dinas yang paling tinggi melakukan pekerjaan terdapat pada Banjar Dinas Loloan Timur $(38,46 \%)$, sedangkan untuk aktifitas pekerjaan yang paling rendah terdapat pada Banjar Dinas Mertasari yaitu $27.48 \%$, tingginya aktifitas pekerjaan yang terjadi di Banjar dinas Loloan timur disebabkan membantu suami mencari nafkah dan mencukupi untuk kebutuhan rumah tangga.

Berdasarkan data yang telah diperoleh di lapangan terdapat variasi jumlah anak yang dimiliki wanita Pasangan Usia Subur (PUS) yang terdapat di Kelurahan Loloan Timur. Jumlah anak wanita Pasangan Usia subur (PUS) paling banyak berkisar pada jumlah anak 1 sampai 2 anak, dan jumlah paling rendah terdapat pada 5 sampai 6 anak. Data tentang jumlah anak wanita Pasangan Usia Subur (PUS) di Kelurahan Loloan Timur.

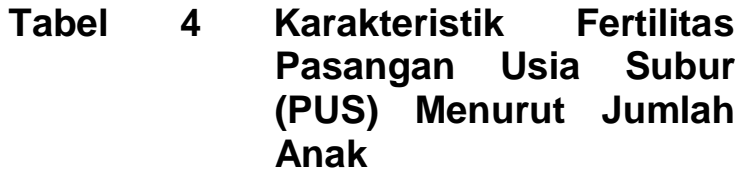




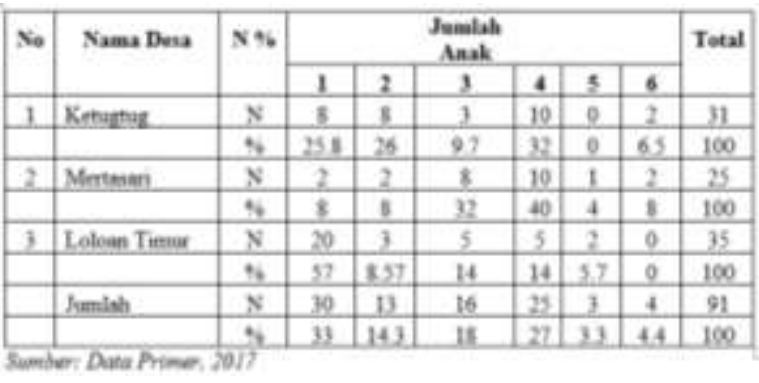

Berdasarkan Tabel 4.12 terlihat jumlah anak yang dimiliki oleh wanita Pasangan Usia Subur (PUS). Kesadaran ber-KB dari wanita PUS masih tergolong rendah, hal ini dibuktikan dengan masih adanya jumlah anak dikisaran 5 sampai 6 anak, namun terdapat daerah dengan jumlah anak yang di dominasi dengan jumlah anak 1 sampai 2 anak yaitu di setiap Banjar.

\section{Hubungan antara aktivitas dan fertilitas wanita pasangan usia subur (PUS) Kelurahan Loloan Timur}

Setelah dilakukan analisis faktor dari dari data aktivitas yang terdiri dari umur, curahan waktu kerja, jenis pekerjaan, dan pendapatan, serta dari data fertilitas yaitu jumlah anak, didapat data aktivitas dan fertilitas sebagai berikut.

Tabel 5 Hubungan antara Curahan jam kerja dengan Jumlah anak

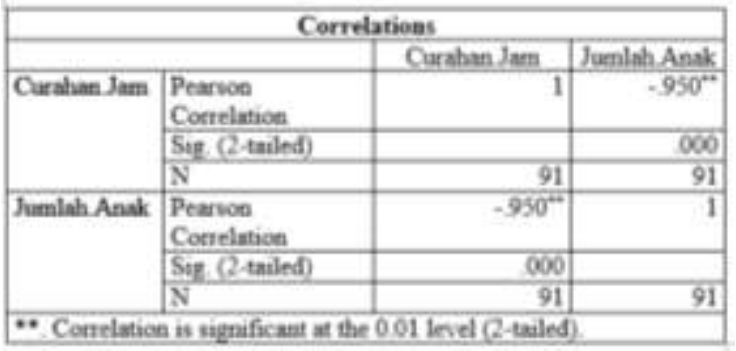

Berdasarkan output dari uji korelasi tersebut terlihat bahwa nilai sig. 000. Nilai sig. kurang dari 0,05 yang berarti bahwa terdapat hubungan antara curahan jam kerja dengan fertilitas wanita pasangan usia subur. Besar korelasinya terlihat dari nilai pearson correlation yaitu -950 . Nilai korelasi ini berarti hubungan antara curahan jam kerja dengan fertilitas sangat besar dan berbanding terbalik yang dicerminkan oleh tanda negatif pada nilai korelasi. Berbanding terbalik ini diartikan bahwa semakin banyak curaham jam kerja yang dilakukan oleh wanita pasangan usia subur, jumlah fertilitasnya semakin sedikit. Begitu juga dengan sebaliknya jika curahan jam kerja wanita pasangan usia subur semakin sedikit, maka fertilitasnya semakin banyak.

Dibandingkan dengan penelitian sebelumnya yang dilakukan Ainun Nurul Laily pada tahun 2012 dari penelitian 100 responden, yang yang bekerja sebagai buruh cuci, wiraswasta, pedagang keliling terbukti bahwa mereka bekerja seperti biasa dan tidak pernah lembur. Hal ini menunjukkan sebagian besar responden tidak memiliki jam kerja padat, sehingga banyak waktu luang yang digunakan untuk menambah frekuensi untuk berhubungan dan menambah fertilitas. Status bekerja merupakan status wanita pasangan usia muda dalam pekerjaan. Semakin banyak jam kerja seseorang maka akan semakin besar produktivitasnya dan semakin banyak waktu yang digunakan untuk bekerja maka akan semakin kecil pula peluang untuk memperoleh anak. Jika waktu yang dicurahkan untuk bekerja cukup lama maka peluang atau frekuensi untuk berhubungan kelamin semakin berkurang dan menyebabkan kelahiran menurun.

\section{Saran}

Berdasarkan hasil pembahasan dan simpulan di atas, maka dapat diajukan beberapa saran sebagai berikut. (1) Hasil penelitian ini diharapkan berguna bagi peneliti lain, yaitu dapat menambah wawasan serta dapat dijadikan bahan acuan atau referensi dalam penelitian lainnya. (2) Penduduk wanita yang memiliki jumlah anak yang banyak diharapkan dapat merencanakan jumlah anak yang dimilki walaupun jumlah waktu lebih banyak kepada keluarga dan mengatur jarak kelahiran anak dengan baik, misalnya dengan menggunakan alat kontrasepsi baik berupa pil maupun suntikan.

\section{DAFTAR RUJUKAN}


Mantra, Ida Bagoes. 2003. Demografi

Umum. Yogyakarta: Pustaka Pelajar.

Astawa, Ida Bagus Made, I Made Sarmita. 2016. Geografi Penduduk. Buku Ajar (tidak diterbitkan). Singaraja: UNDIKSHA.

Kantor Kelurahan Loloan Timur. 2014.Laporan Penduduk 2014. Jembrana:Kantor Kelurahan Loloan Timur.

Nurul Laily A. 2012. Analisis Fertilitas Di Kecamatan Bangsalsari Kabupaten Jember. Skripsi tidak diterbitkan. Jember: FE UENEJ. 